\title{
TAKDIR DAN KEBEBASAN MENURUT FETHULLAH GÜLEN
}

\author{
Anang Haderi \\ Forum Studi Islam dan Sosial (FoSIS) \\ Alumni Universitas Antakusuma (UNTAMA) Pangkalan Bun, \\ Kalimantan Tengah \\ e-mail: hadrise@yahoo.co.id
}

\begin{abstract}
Destiny and free will is one of issues in Islamic theology which is still discussed by Moslem theologian up to now. This discussion has yielded some streams with its argumentation respectively. Included who intense to discuss this issue is muhammad Fethullah Gülen. At a glance, he offers to explain the issue in his own way without following one of the streams. He introduces some key terms, like Imām Mubin, Kitāb Mubīn, Lauh Mahfüz, Formal or Theoretical Destiny, actual destiny. Terms are Gülen's exclusive. The article will elaborate the explaination of Gülen relating to the destiny and free will. The purpose is to map what is he follows the streams or he has interpretation in himself. For this reason, I will spread out briefly views of theologian before, i.e. these streams of Mu'tazili, al-Asy'arite, Matūridite Samarkand dan Matūridite Bukhārā. By this way it will be seen clearly where is the position of Gülen and what is contribution of his thinking.
\end{abstract}

Abstrak: takdir dan kebebasan adalah isu teologi Islam yang masih diperbincangkan oleh para teolog hingga sekarang. Perdebatan ini telah melahirkan berbagai aliran dengan pendapatnya masing-masing.Termasuk yang juga intens membahas isu ini adalah Muḥammad Fethullah Gülen. Sekilas, ia berusaha menjelaskan isu ini dengan caranya sendiri tanpa mengikuti salah satu aliran tersebut. Ia mengenalkan beberapa istilah kunci, seperti Imām Mubīn,Kitāb Mubīn, Lauh Maḩüz, takdir formal, takdir teoritis, dan takdir aktual. Istilah-istilah ini merupakan khas Gülen. Tulisan ini akan mengelaborasi penjelasan Gülen mengenai takdir dan kebebasan tersebut. Tujuannya adalah memetakan apakah ia mengikuti aliranaliran teologi yang sudah ada ataukah ia mempunyai pemaknaan sendiri terhadap persoalan ini. Untuk alasan ini, 
ANANG HADERI: Takdir dan Kebebasan

penulis akan memaparkan secara singkat pendapat para teolog sebelumnya, yakni aliran-aliran Mu'tazilah, alAsy'ariyah, Mātūridiyah Samarkand dan Mātūridiyah Bukhārā. Dengan cara ini akan terlihat dengan jelas di manakah posisi Gülen dan apa kontribusi dari pemikirannya itu.

Keywords:Imām Mubīn,Kitāb Mubīn, Lauḥ Mahfūz, takdir formal, takdir aktual.

\section{A. Pendahuluan}

Muhammad Fethullah Gülen adalah seorang ulama dan pemikir besar dari Turki modern, yang oleh kalangan dekatnya disebut sebagai Hodjaefendi.Ia telah menulis berbagai disiplin ilmu: tasawuf, tafsir, sejarah, filsafat, dan teologi, dengan menggunakan bahasa yang indah dan kontekstual serta jauh dari sikap-sikap apologia dan provokatif. Dalam tulisan ini, penulis akan membahas pemikiran teologi Fethullah Gülen yang berkaitan dengan takdir dan kehendak bebas.

Semua Muslim dan aliran teologi Islam sepakat mengatakan bahwa Allah adalah Tuhan Yang Maha Kuasa dan Maha Adil dalam menentukan takdir dan berkehendak.Namun ketika membahas masalah free will (kehendak bebas) dan predestination (takdir, fatalisme) menjadi bahan perdebatan yang sangat sengit di kalangan teolog.Oleh karena Allah yang telah mencipta dan mengukur alam semesta dan semua makhluk yang terdapat di dalamnya, tentunya Dia pula yang memiliki kehendak dan kekuasaan yang mengatasi kehendak dan kekuasaan makhluk-Nya. Pertanyaanya adalah apakah kehendak dan kekuasaan tersebut bersifat mutlak ataukah terbatas, para ulama kalam (teolog) berbeda pendapat dalam menjawab persoalan ini. ${ }^{1}$ Jawaban terhadap pertanyaan ini, para ahli secara umum mengkategorikan aliran para teolog ke dalam dua kategori: rasional dan tradisional. Setiap aliran menyandarkan pendapat mereka kepada al-Quran (lihat Tabel 1). ${ }^{2}$ 
Tabel 1

Free Will dan Predestination

\begin{tabular}{|c|c|c|}
\hline $\begin{array}{l}\text { Aliran } \\
\text { Teologi }\end{array}$ & Kategori & Rujukan Al-Qur'an \\
\hline Mu'tazilah & Rasional & $\begin{array}{l}\text { QS. Ali Imrān [3]: 133; al-Nisā' [4]: 79; } \\
\text { al-Baqarah [2]: 108; al-Ahqāff [46]: 14; } \\
\text { al-Taubah [9]: 82; al-Kahfi [18]: 29; dan } \\
\text { al-Taghābun [64]: } 2\end{array}$ \\
\hline $\begin{array}{l}\text { Mātūridiyah } \\
\text { Samarkand }\end{array}$ & Rasional & $\begin{array}{l}\text { QS. Ali Imrān [3]: 133; al-Nisā' [4]: 79; } \\
\text { al-Baqarah [2]: 108; al-Ahqāf [46]: 14; } \\
\text { al-Taubah [9]: 82; al-Kahfi [18]: 29; dan } \\
\text { al-Taghābun [64]: } 2\end{array}$ \\
\hline Al-Asy'ariyah & Tradisional & QS. al-Ṣaffat [37]: 96; al-Insān [76]: 30 \\
\hline $\begin{array}{l}\text { Mātūridiyah } \\
\text { Bukhārā }\end{array}$ & Tradisional & $\begin{array}{l}\text { QS. al-Mulk [67]: 13-14; al-Rūm [30]: } \\
\text { 22; al-Ra'd [13]: } 16 .\end{array}$ \\
\hline
\end{tabular}

Aliran kalam (teologi) rasional (Mu'tazilah) yang memberikan daya besar kepada akal berpendirian bahwa manusia mempunyai kebebasan dalam berkehendak dan berkuasa atas perbuatan-perbuatannya. ${ }^{3}$ Aliran ini membatasi kehendak dan kekuasaan Allah itu adalah (a) kebebasan yang telah diberikan-Nya kepada manusia untuk memilih dan melakukan perbuatanya, (b) sunnah-Nya dalam mengatur alam semesta dan makhluk-Nya, (c) norma keadilan, dan (d) kewajiban yang telah ditetapkan-Nya atas diri-Nya terhadap manusia. ${ }^{4}$ Sebaliknya, aliran kalam tradisional menempatkan manusia pada posisi lemah dan banyak bergantung pada kekuasaan dan kehendak mutlak Tuhan.Asy'ari, sebagai tokoh sentral aliran ini, dalam menjelaskan masalah free will dan predestination, menampilkan teori al-kasb (acquisition, perolehan). Al-Kasb, menurut Asy'ari, adalah sesuatu yang terjadi dengan perantaraan daya yang diciptakan, atau sesuatu yang timbul dari al-muktasib (orang yang memperoleh) dengan perantaraan daya yang diciptakan. ${ }^{5}$ Aliran ini 
ANANG HADERI: Takdir dan Kebebasan

juga menegaskan bahwa Allah memiliki kehendak yang mutlak. Karena itu, Dia dapat berbuat apa saja secara sewenang-wenang pada makhluk-Nya, sesuai dengan kehendak-Nya, tanpa ada yang membatasi dan melarang-Nya. Bahkan, Dia dapat saja memberikan hidayah dan menyesatkan hamba-hamba-Nya secara paksa, memasukkan orang-orang kafir dan jahat ke dalam surga. ${ }^{6}$

Selain dua aliran di atas, ada aliran Mātūridiyah Samarkand dan Mātūridiyah Bukharā.Mātūridiyah Samarkand membagi dua perbuatan kepada perbuatan Tuhan dan perbuatan manusia. Perbuatan Tuhan mengambil bentuk penciptaan daya dalam diri manusia sedangkan pemakaian daya tersebut adalah perbuatan manusia sendiri. Oleh sebab itu, manusia dalam pandangan aliran ini mempunyai kebebasan dalam melakukan perbuatannya, dan perbuatan itu adalah perbuatan manusia sendiri dalam arti sebenarnya bukan dalam arti kiasan. ${ }^{7}$

Aliran kalam Mātūridiyah Bukhārā sepaham dengan Mātūridiyah Samarkand ketika sama-sama mengatakan terdapat dua daya dalam diri manusia. Namun Mātūridiyah Bukhārā berbeda dengan Mātūridiyah Samarkand dalam hal daya penciptaan manusia. Bazdawī, yang merupakan representasi dari Mātūridiyah Bukhārā, menjelaskan bahwa manusia tidak mempunyai daya untuk mencipta.Daya yang ada pada diri manusia itu hanya bisa untuk menjadikan manusia mampu melakukan perbuatannya. Dalam hal ini, hanya Tuhan yang dapat mencipta dan dalam ciptaan itu terdapat perbuatan manusia.Ini berarti manusia hanya dapat melakukan perbuatan yang sudah diciptakan Tuhan bagi dirinya. ${ }^{8}$

Dengan deskripsi singkat dari aliran teologi Islam di atas, tulisan ini akan mengeksplorasi lebih dalam pemikiran Fethullah Gülen mengenai takdir dan kebebasan manusia serta status manusia yang lahir di negeri non-Islam. Setelah akan diketahui di manakah sesungguhnya posisi ulama terkemuka asal Turki tersebut. 


\section{B. Sekilas tentang Fethullah Gülen}

Ia adalah Muhammad Fethullah Gülen, lahir di Erzurum9 ${ }^{9}$, sebuah kota di bagian Anatolia Timur, Turki, pada 27 April 194110, dari pasangan Ramiz dan Refia. ${ }^{11}$ Pendidikan dasarnya dimulai sejak ia tinggal di daerah asalnya Erzurum. Sejak belia ia sudah menghafal al-Quran dan belajar Ilmu Agama di sejumlah Madrasah. Karier pertamanya sebagai seorang dai bahkan telah dimulai sejak usianya 14 tahun. Ia juga secara autodidak mempelajari berbagai disiplin ilmu lain terutama Ilmu Pengetahuan Alam dan Sosial seperti fisika, kimia, biologi, geografi, filsafat, juga kesusastraan Timur dan Barat. ${ }^{12}$ Karena kondisi sosial-politik yang tidak baik dan cenderung "memusuhi" Fethullah Gülen, maka pada tahun 1999, ia tiba di Negeri Paman Sam (Amerika Serikat) dengan tujuan berobat. Iamemang menderita diabetes dan gangguan jantung. Iamengalami operasi jantung pada tahun 2004, dan para dokter merekomendasikan kepada Gülen untuk menghindari stres. Untuk alasan ini, ia memilih hidup jauh dari atmosfir hiruk-pikuk politik di Turki, dan dijamin secara permanen oleh pemerintah Amerika Serikat pada tahun 2006. Ia juga salah satu ulama yang secara terang-terangan mengutuk serangan 11 September. Menurut beliau, tragedi 11 September ini merupakan pukulan hebat bagi perdamaian dunia. Ia menegaskan bahwa teror tidak pernah bisa digunakan atas nama Islam karena seorang Muslim yang sejati tidak mungkin menjadi teroris. Muslim seharusnya menjadi representasi dan simbol perdamaian, kesejahteraan, dan kemakmuran. ${ }^{13}$

Pada 2008 Majalah paling populer di Amerika, Foreign Policy Magazine bahkan menobatkannya sebagai orang nomor satu dari 100 tokoh paling berpengaruh di dunia. Kini meski ia tinggal di kota Pennsylvania-Amerika, gerakan-gerakannya serta pemikiranpemikirannya telah tersebar ke seluruh penjuru dunia. Ajarannya tentang Hizmet (pelayanan terhadap umat manusia), telah menarik 
ANANG HADERI: Takdir dan Kebebasan

perhatian sejumlah pendukungnya di Turki, Asia Tengah, juga tokohtokoh penting lainnya di berbagai penjuru dunia.

Bagi banyak orang, Fethullah Gülen dipandang sebagai tokoh dengan pandangan-pandangan yang moderat. Tapi banyak pula yang menuduhnya sebagai kepanjangan tangan dari Mustofa Kemal Ataturk dengan sekulerismenya yang ingin mengebiri Islam dari kehidupan politik di Turki. ${ }^{14}$ Gülen dipandang mengajarkan Islam Sunni-Hanafi yang moderat, mirip dengan pengajaran Said Nursi. Gülen mengutuk terorisme, mendukung dialog lintas-agama, dan memprakarsai dialog semacam itu dengan Vatikan dan beberapa organisasi Yahudi.

Fethullah Gülen mendirikan gerakan Gülen yang bergerak di bidang pendidikan. Ratusan sekolah dan universitas telah ia dirikan di Turki dan di beberapa negara Islam bekas jajahan Uni Soviet. Ia juga telah mendirikan beberapa stasiun radio dan koran serta majalah Zaman sebagai media komunikasi dengan masyarakat luas. Karena alasan politik di Turki, ia pindah ke Amerika Serikat. Pada tahun 1980 ia dituduh terlibat dalam kudeta militer. Tahun 1997 juga dituduh terlibat dalam soft coup untuk menumbangkan pemerintahan Islamist pimpinan Perdana Menteri Necmettin Erbakan. Erbakan akhirnya tumbang. Sejak saat itu, Gülen sering mendapat ancaman dari kaum Islamist dan memaksanya untuk hijrah ke Amerika Serikat.

Fethullah Gülen aktif sebagai penulis dan pemimpin gerakannya yang berskala internasional. Hingga kini, tak kurang dari 70 buku telah ia tulis, dan lebih dari 1000 kaset dan CD mengenai ceramahceramah beliau telah dipublikasikan, di samping sejumlah artikel dalam berbagai jurnal. Topiknya beragam, baik mengenai pendidikan, hubungan antaragama, dan keadilan. Karya-karya tulisnya kini sudah diterjemahkan ke dalam 40 bahasa, antara lain Inggris, Jerman, Rusia, Albania, Jepang, Korea, Spanyol, dan Indonesia. ${ }^{15}$ Gülen banyak menuangkan pemikiran-pemikiran ten- 
tang pembaruan di dunia Islam dan lebih mengedepankan dialog dan perdamaian antar umat beragama dalam menyebarkan ajaran dan nilai-nilai Islam. Pemikiran-pemikirannya ini kemudian menjadi sebuah gerakan yang diwujudkan dalam bentuk lembaga-lembaga pendidikan, lembaga amal, media massa cetak dan elektronik, perkumpulan-perkumpulan pelajar dan kelompok-kelompok lobi, bahkan membantu berdirinya asosiasi wartawan dan penulis (Journalists and Writers Foundation) di Turki pada tahun 1994. Gerakan Gülen juga memiliki media sendiri, termasuk koran Zaman, saluran tv Samanyolu, dan stasion radio Burc. Mereka juga memproduksi acara video dan audio. Mereka yang terlibat termasuk intelektual-intelektual kenamaan dari berbagai universitas bergengsi di Turki.

Buku-buku yang telah ditulis Fethullah Gülen, antara lain, Towards the Lost Paradise (1998), Fethullah Gülen: Advocate of Dialogue (2000), Essentials of the Islamic Faith; Pearls of Wisdom(2000), Essays, Perspectives, Opinions (2002), Love and the Essence of Being Human(2004), Toward a Global Civilization of Love and Tolerance(2004), Emerald Hills of the Heart: Key Concepts in the Practice of Sufism (3 volume, 2004, 2008), The Necessity of Interfaith Dialog. A Muslim Perspective (2004), Muhammad, the Messenger of God: Aspects of His Life I (2005), Questions and Answers about Islam (2 volume, 2005, 2006), The Statue of Our Souls. Revival in Islamic Thought (2 volume, 2005), Fatiha Üzerine Mülāhazalar (2007), Vuslat Muştusu (Kırık Testi, 8, 2008), Kitap ve sünnet perspektifinde Kader (2009), Kur'ān'dan İdrake Yansıyanlar (2009), Hitap Çiçekleri (2009), dan Enginliğiyle Bizim Dünyamı (2009), dan masih banyak lagi yang lainnya. ${ }^{16}$

\section{Pemikiran tentang Takdir}

Menurut pemahaman Fethullah Gülen, takdir adalah segala sesuatu yang ada, mulai dari partikel sub-atom sampai alam semesta 
ANANG HADERI: Takdir dan Kebebasan

secara keseluruhan, diketahui oleh Allah Yang Maha Kuasa.Pengetahuan-Nya meliputi semua ruang dan waktu, sedangkan Dia sendiri benar-benar bebas dari ketentuan dan takdir tersebut.Segala sesuatu Dia ketahui, dan Dia menentukan bentuk, rentang kehidupan, fungsi atau misi, dan karakter tertentu pada setiap ciptaan-Nya. ${ }^{17}$ Ia menganalogikan takdir sebagai berikut:

Authors have full and exact knowledge of the books they will write, and arrange its contents before writing it. In this sense, Destiny is almost identical with Divine Knowledge, or is a title of Divine Knowledge. It is therefore also called the "Supreme Preserved Tablet" (or the "Manifest Record"). Destiny also means that God makes everything according to a certain, particular measure and in exact balance: God knows what every female bears and what the wombs absorb and what they grow. And everything with Him is measured. (13:8); The sun and the moon are made punctual according to a calculation. The stars and the trees adore, in subservience to Him. And the sky He has uplifted; and He has set the balance, that you exceed not the balance, but observe the balance strictly, nor fall short thereof(55:5-9).18

Para penulis memiliki pengetahuan penuh dan sempurna tentang buku-buku yang akan mereka tulis, dan merancang isinya sebelum menulis. Dalam hal ini, Takdir sama dengan Pengetahuan Tuhan, atau suatu istilah untuk Pengetahuan Tuhan. Karena itu disebut juga "Lauh Maḥfūz" (atau "Imām Mubīn"). Takdir juga berarti bahwa Tuhan membuat segala sesuatu sesuai dengan ukuran khusus tertentu dan benar-benar seimbang: Allah mengetahui apa yang dikandung oleh setiap perempuan, dan kandungan rahim yang kurang sempurna dan yang bertambah. Dan segala sesuatu pada sisi-Nya dan ukurannya (QS. al-Ra'd [13]: 8); Matahari dan bulan (beredar) menurut perhitungan. Dan tumbuh-tumbuhan dan pohonpohonan kedua-duanya tunduk kepada-Nya.Dan Allah telah meninggikan langit dan Dia meletakkan necara (keseimbangan).Supaya kamu jangan melampaui batas tentang neraca itu. 
Dan tegakkanlah timbangan itu dengan adil dan janganlah kamu mengurangi neraca itu (QS. al-Raḥmān [55]: 5-9).

Adanya ukuran dan keseimbangan, keteraturan dan keselarasan, alam semesta beserta semua isinya, dengan jelas menunjukkan bahwa segala sesuatu ditentukan dan diukur, diciptakan dan diatur oleh Allah Yang Maha Kuasa.Berdasarkan kenyataan ini, menurut Fethullah Güleh, takdir Allah itu ada. ${ }^{19}$ Di sini, ia menegaskan bahwa bentuk-bentuk yang diukur dan proporsional, dan keteraturan serta keselarasan yang luar biasa dari alam semesta ini yang telah berlangsung miliaran tahun tanpa gangguan atau kerusakan menunjukkan bahwa segala sesuatu terjadi sesuai dengan ketentuan absolut Allah Yang Maha Kuasa. ${ }^{20}$ Selain itu, Allah juga berkuasa mutlak mempekerjakan atom-atom dan partikel, sesuai dengan yang ditentukan oleh takdir-Nya.

Di bagian lain, Fethullah Gülen mengenalkan dua istilah kunci, "Imām Mubīn dan Kitāb Mubīn", yang merefleksikan pemikirannya terhadap konsep takdir.Kata imām mubīn, misalnya, dapat ditemukan dalam QS. Yā Sīn [36]: 12, wa kulla sya'in ahṣaināhu fi imāmin mubīn (dan segala sesuatu Kami kumpulkan di dalam lauh mahfüz yang nyata). Ada yang berpendapat bahwa imām di dalam ayat ini berarti 'lembaran-lembaran amal perbuatan manusia', di samping itu ada yang memahaminya sebagai 'ilmu Allah'. ${ }^{21}$ Fethullah Gülen cenderung memaknai 'imām mubīn' dengan makna yang lebih luas dari sekedar 'Ilmu Allah'. Sebutan ini, menurutnya, merujuk pada "Divine Knowledge and Command, includes all things and events in the universe. That is, every thing and event has a pre-existence in Divine Knowledge. When it is time for them to come into the world or when God wills to bring them into the world, He clothes them in material existence" (Pengetahuan dan Perintah Allah, mencakup semua hal dan peristiwa di alam semesta.Yaitu, segala hal dan peristiwa memiliki pra-eksistensi dalam Pengetahuan Allah.Ketika tiba waktunya bagi mereka untuk lahir ke dunia atau ketika Allah 
ANANG HADERI: Takdir dan Kebebasan

berkehendak membawanya ke dalam dunia, Dia menutupi mereka dalam eksistensi lahiriah). ${ }^{22}$

Dijelaskan lebih lanjut oleh Gülen bahwa sebutir biji berisi masa depan kehidupan tanaman yang akan berkembang darinya. Kehidupan tanaman juga akan berakhir dalam biji-bijian, masingmasing biji tersebut dapat dianggap sebagai memori tanaman. Tanaman-tanaman baru yang akan tumbuh dari bijian-bijian itu sangat mirip dengan nama aslinya, karena tidak ada di antara mereka yang memiliki suatu roh yang sadar dan disertai kemauan. Dengan demikian, di samping berfungsi sebagai analogi untuk Imām Mubīn dan Takdir, serta Pengetahuan Allah, sebutir biji juga menunjukkan Laụ̣ Maḥfüz, dan menghubungkannya dengan memori manusia dalam dunia manusia. Selain itu, karena sebutir biji menunjukkan bahwa riwayat kehidupan makhluk sudah tertulis, maka juga menunjukkan tentang kehidupan sesudah mati. ${ }^{23}$

Dalam al-Quran, selain sebutan Imām Mubīn terdapat sebutan Kitāb Mubīn; kata mubīn di dalam al-Quran digunakan sebagai sifat atau keadaan, baik yang menunjukkan sesuatu yang baik maupun sesuatu yang jelek. ${ }^{24}$ Menurut Fethullah Gülen, Kitāb Mubìn adalah sebutan lain untuk Kehendak Allah dan ciptaan Allah serta hukum operasional alam semesta ini.Jika Imām Mubīn sebagai Takdir Formal atau Teoritis (Formal or Theoretical Destiny), maka Kitāb Mubīn dapat dianggap sebagai Takdir Aktual. Bentuk sempurna masa depan suatu tanaman atau makhluk hidup, yang menggambarkan semua isi biji-bijian atau sel telur yang subur, dapat dipahami sebagai Takdir Aktual (Actual Destiny). ${ }^{25}$ Tegasnya, tulis Fethullah Gülen,

like seeds or plants or fertilized ovums and living beings, everything that exists clearly points to Divine Destiny, determining and judging, as well as measuring, particularizing, and individualizing. True dreams that inform us of certain future events are another, undeniable indication of Destiny or Divine predetermination. ${ }^{26}$ 
Seperti biji-bijian atau tanaman atau sel telur yang subur dan makhluk hidup, segala sesuatu yang ada dengan jelas menunjukkan Takdir Tuhan, menentukan dan menilai, serta mengukur, memberi sifat khusus, dan membedakan. Impianimpian nyata yang menginformasikan kepada kita tentang peristiwa masa depan tertentu adalah indikasi lainnya yang tidak dapat disangkal mengenai Takdir atau Ketentuan Tuhan.

Dengan demikian, beriman kepada takdir adalah salah satu keyakinan penting. Jika muncul pertanyaan: mengapa iman kepada takdir merupakan salah satu keyakinan penting? Fethullah Gülen memberikan jawaban sebagai berikut: "Kesombongan diri dan ketaatan kita yang lemah menyebabkan kita mempersembahkan keahlian dan amal baik kita untuk diri kita sendiri dan merasa bangga kepada diri sendiri. Tetapi al-Quran secara eksplisit menyebutkan: padahal Allah-lah yang menciptakan kamu dan apa yang kamu perbuat itu (QS. al-Șāffat [37]: 96), yang berarti bahwa Belas Kasihan Allah (Divine Compassion) memerlukan amal baik dan bahwa Kekuasaan Allah-lah yang mencipatakn mereka. Apabila kita menganalisis kehidupan kita, akhirnya kita menyadari dan mengakui bahwa Allah membimbing kita kepada perbuatan-perbuatan baik dan biasanya mencegah kita dari hal-hal yang salah."27

Ditambahkan Gülen, yang masuk dalam takdir itu adalah kapasitas, kekuatan, dan peralatan yang memadai untuk mendapatkan banyak hal, yang menyebabkan kita mampu menyadari berbagai kemahiran dan amal-amal baik. Karena Allah membimbing kita menuju amal kebaikan dan menyebabkan kita menginginkan dan kemudian melaksanakannya, penyebab nyata amal baik kita adalah kehendak Allah (Divine Will).Kita dapat "memiliki" amal baik kita hanya melalui keimanan, ketaatan yang tulus, berdoa agar selalu patut mendapatkan keduanya, secara sadar yakin perlu menjalankannya, dan senang atas segala yang telah diatur Allah. Dengan demikian, tegas Gülen, "There is no reason for us to boast or be proud; rather, we should remain humble and thank God."28Dalam 
ANANG HADERI: Takdir dan Kebebasan

hal ini, kita tidak boleh merasa bangga atas amal baik yang dilakukan, melainkan harus tetap rendah hati dan bersyukur kepada Allah atas semuanya itu. Jika tidak, bisa saja anugerah itu Dia ambil kembali.

Adapun berkaitan dengan perbuatan buruk yang dilakukan oleh seseorang, Fethullah Gülen berpendapat bahwa perbuatan itu tidak bisa dinisbahkan sebagai takdir Tuhan.Perbuatan tersebut adalah tanggung jawab manusia.Dosa akibat perbuatan itu adalah risiko manusia. Alasan Gülen, karena Tuhan tidak menyukai atau membenarkan perbuatan semacam itu, semua dosa dan kesalahan itu milik kita dan dilakukan atas kemauan kita. Gülen lebih jauh menyatakan:

Allah memperbolehkan dosa dan memberi mereka bentukbentuk eksternal, karena Dia tidak melakukan hal itu, kemauan kita akan tidak berguna. Dosa-dosa merupakan akibat dari keputusan kita, melalui kemauan kita, untuk berbuat dosa. Allah memanggil dan membimbing kita menuju perbuatan baik, bahkan menyertakan mereka di dalam diri kita, tetapi kemauan akan memungkinkan kita tidak mentaati Sang Pencipta kita. Oleh karena itu, kita "memiliki" dosa-dosa dan perbuatan buruk kita. Untuk melindungi diri kita dari dosa dan godaan setan serta godaan jasmaniah, menuruti ajakan setan, kita harus berjuang untuk menghilangkan atau mendisiplinkan penyelewengan kita menuju dosa melalui taubat dan meminta ampunan atas dosa dan perbuatan buruk tersebut. Selain itu, kita harus mengarahkan dan mendorong diri kita sendiri untuk melakukan perbuatan-perbuatan baik melalui doa, ketaatan, dan percaya kepada Allah. ${ }^{29}$

Dari penjelasan di atas, jelaslah bahwa perbuatan buruk atau dosa yang dilakukan oleh seseorang adalah bersumber dari dirinya sendiri bukan dari Tuhan.jika kita merujuk pada QS.al-A'rāf [7]: 172 dan al-Rūm [30]: 30, pada dasarnya fitrah manusia itu lebih mengutamakan kebaikan daripada keburukan dan lebih mendahulukan yang bermanfaat daripada yang berbahaya. Setiap potensi yang 
dimiliki fitrah manusia itu akan memberikan manfaat apabila potensi itu digunakan dengan baik. Karena itu, orang terpuruk pada keburukan, pada galibnya adalah karena ia tidak profesional dalam menggunakan potensi tersebut. ${ }^{30}$

Yang menarik dari pemikiran takdir Fethullah Gülen ini adalah bahwa kita bisa menisbahkan apa yang sudah terjadi sebagai takdir dengan tujuan untuk mendapatkan solusi. Pemikirannya ini berdasarkan pada tabiat manusia yang biasanya mengeluh atas peristiwa-peristiwa dan penderitaan di masa lalu. Bahkan, lebih buruk lagi, kita kadangkala putus asa dan menelantarkan diri kita sendiri dalam gaya hidup yang keji, dan bahkan mulai mengeluh kepada Allah. Di sinilah, menurutnya, takdir memungkinkan kita menghubungkan peristiwa dan penderitaan masa lalu dengan keluhan itu sehingga kita bisa mendapatkan kelegaan, keamanan, dan pelipur lara. Gülen menulis:

So, whatever happened in the past should be considered in the light of Destiny; what is to come, as well as sins and questions of responsibility, should be referred to human free will. In this way, the extremes of fatalism (jabr) and denying Destiny's role in human actions (i'tizal, the view of the Mu'tazila) is reconciled. ${ }^{31}$

Sehingga, apa pun yang terjadi di masa lalu harus dianggap kehendak Allah; apa yang akan terjadi, juga dosa-dosa dan masalah tanggung jawab, seharusnya dianggap sebagai kemauan manusia. Dalam hal ini, fatalisme (keyakinan bahwa segala sesuatu telah ditakdirkan) yang ekstrim, dan penyangkalan terhadap peranan Allah di dalam tindakan manusia (pandangan para Mu'tazilah) diterima.

\section{Tentang Kehendak dan Kemampuan Manusia}

Berkaitan dengan kehendak bebas manusia, Fethullah Gülen mengingatkan tentang adanya kesempatan bagi manusia untuk menentukan tindakannya.Menurutnya, kehendak atau kemauan manusia tergantung pada pilihan masing-masing.Sepanjang sejarah 
ANANG HADERI: Takdir dan Kebebasan

manusia telah berusaha membedakan atau menyesuaikan Kehendak Allah dengan kemauan manusia.Ada orang-orang yang mengingkari adanya kemauan, sedangkan yang lainnya menyatakan bahwa kita menciptakan perbuatan kita sendiri dan oleh karena itu mengabaikan takdir. Namun demikian, karena Islam berada di pertengahan dalam segala hal, Islam menyatakan bahwa takdir Allah mendominasi eksistensi, termasuk dunia manusia, tetapi kita dapat menggunakan kemauan kita untuk mengarahkan hidup kita. ${ }^{32}$ Untuk mendukung penjelasannya, Fethullah Gülen mengutip al-Quran yang menyebutkan: "Al-Quran tiada lain hanyalah peringatan bagi semesta alam, (yaitu) bagi siapa di antara kamu yang menempuh jalan yang lurus. Dan kamu tidak dapat menghendaki (menempuh jalan itu) kecuali apabila dikehendaki Allah, Tuhan semesta alam" (QS. alTakwīr [81]: 27-29). Firman ini, menurut Gülen, bahwa kehendak yang absolut adalah milik Allah, tetapi tidak menyangkal kehendak manusia. ${ }^{33}$ Ia juga mengutip ayat lain (QS. al-Șāffat [37]: 96): "Allahlah yang menciptakan kamu dan apa yang kamu perbuat." Bahkan, alQuran juga menerangkan tentang perjanjian antara kita dengan Allah, dengan secara jelas menyebutkan bahwa kita mengatur sejarah: penuhilah janjimu kepada-Ku, niscaya Aku penuhi janji-Ku kepadamu (QS. al-Baqarah [2]: 40); jika kamu menolong (agama) Allah, niscaya Dia akan menolongmu dan meneguhkan kedudukanmu (QS. Muḥammad [47]: 7); sesungguhnya Allah tidak mengubah keadaan sesuatu kaum sehingga mereka mengubah keadaan yang ada pada diri mereka sendiri (QS. al-Ra'd [13]: 11). ${ }^{34}$

Di lain tempat, Fethullah Gülen mengutip ayat ini "Allah membiarkan dalam kesesatan siapa saja yang Dia kehendaki dan memberi petunjuk kepada siapa yang Dia kehendaki"(QS. al-Muddaššir [74]: $31)^{35}$, yang jelas-jelas menunjukkan Allah mengontrol kita. ${ }^{36}$ Demikian juga ayat: "Dan jika Tuhanmu menghendaki, tentulah beriman semua orang yang di muka bumi seluruhnya" (QS. Yūnus [10]: 99); dari ayat ini, menurut Gülen, Allah dapat menciptakan manusia yang baik dan taat, dan dapat pula menciptakan manusia 
yang ingkar dan membangkang. ${ }^{37}$ Juga, ketika ia menafsirkan ayat "Dan tiap-tiap manusia itu telah Kami tetapkan amal perbuatannya (sebagaimana tetapnya kalung) pada lehernya. Dan Kami keluarkan baginya pada hari kiamat sebuah kitab yang dijumpainya terbuka" (QS. al-Isrā [17]: 13), dengan "setiap orang telah ditetapkan baginya segala perbuatan yang akan ia lakukan sepanjang hidupnya dan ketetapan itu dikalungkan di atas lehernya, seolah-olah setiap orang akan digiring ke tempat penggantungan dirinya."38Ulama sebelumnya Gülen, Rasyīd Riḍā mempunyai pendapat senada. Rị̣ā menjelaskan bahwa siapa saja yang hendak disesatkan Allah, disesatkan-Nya orang itu sebagaimana Dia telah menyesatkan mereka yang lebih menyenangi kesesatan daripada petunjuk dan menyesatkan mereka yang tidak mau menggunakan pendengaran, penglihatan, dan akal mereka untuk mengetahui dan memahami ayat-ayat Allah yang membuktikan kebenaran risalah yang disampaikan rasul-Nya. ${ }^{39}$

Menurut Fethullah Gülen, Allah telah memberi manusia akal, intelek, dan kehendak bebas sehingga manusia dapat memilih jalan kebaikan atau kejahatan. ${ }^{40}$ Akal adalah sebuah "entitas" yang terlepas dari materi, meski ia melekat pada materi. Akal adalah kepanjangan yang bersifat cahaya (nūrāni) dari alam gaib ke alam nyata.Akal adalah bagian terpenting dari ruh, dan merupakan entitas paling terang dan paling bersinar dari eksistensi manusia.Akal adalah pemisah antara yang hak dan yang batil. Fethullah Gülen menulis:

Dengan akal, manusia dapat meluruskan apa yang dilihat mata dan didengar telinga, sehingga ia pun dapat sampai kepada ketepatan. Dengan bukti kebenaran yang dicerna oleh akal manusia dapat menembus batas di balik tirai wujud. Bahkan dengan akal-lah manusia dapat naik menuju maqām audiensi di hadapan Allah jalla wa 'alā. Karena memiliki akal, manusia berhak mengemban beberapa tanggung jawabnya, baik yang bersifat paksaan (jabariyah) maupun bersifat pilihan (ikhtiyāri- 
ANANG HADERI: Takdir dan Kebebasan

yah). Kemudian ia melanglang buana mengeksplorasi jagad raya dan kejadian-kejadian, menelitinya, menggalinya, dan kemudian melesat menuju hadirat Allah Ta'āla. ${ }^{41}$

Dalam kebaikan dan hal-hal terpuji, akal akan menghimpun logika dan pikiran kita bersama kekayaan tak terbatas yang ada pada wahyu dan ilham, untuk kemudian menjadi referensi bagi semua seruan yang muncul dari alam transendental. Adapun dalam keburukan dan hal-hal tercela, akal akan memberikan penafsiran logis bagi hukum-hukum Ilahi, untuk kemudian mengontrol ekses yang muncul dari berbagai hasrat menyimpang yang ditimbulkan hawa nafsu, dan sekaligus menyusun strategi untuk melawan serangan hawa nafsu itu. ${ }^{42}$

Ditambahkan Fethullah Gülen, bahwa Allah telah membuka pintu hidayah dan keimanan atau petunjuk-Nya bagi orang-orang yang mau beriman, sehingga Dia mengutus beberapa rasul dan nabi kepada manusia secara umum. Selain itu, Allah juga menjadikan sejumlah dai untuk mengajak manusia ke jalan kebaikan. Tetapi, sebagian ada yang menentang ajakan mereka, bahkan mereka membunuh para nabi dan sebagian orang yang mengajak kebaikan. ${ }^{43}$ Allah tidak menyebabkan siapa saja tersesat, kecuali mereka yang Dia tahu hendak menolak untuk beriman.Di sini, tegas Gülen, membiarkan kepada kesesatan berarti Allah membiarkan seseorang sendirian dan mencabut berkah-Nya atas dirinya. Allah mungkin akan meninggalkan orang yang Dia tahu akan memilih untuk menyangkal kebenaran dan bertahan dalam penolakan itu. Mendapatkan pertolongan dan berkah-Nya atau dicabut dari pertolongan dan berkah-Nya, itu semua tergantung kepada pilihan bebas kita saja.44 Singkatnya, "manusialah yang harus mampu dengan sebaik-baiknya menjadikan perjalanan sejarah mereka selama menghuni bumi sebagai "darah dan daging" bagi kehidupan mereka di saat ini dan masa depan."45 


\section{Status Manusia Terlahir dan Hidup di Negara Non-Islam}

Persoalan teologis yang sering muncul juga adalah nasib manusia yang dilahirkan dan hidup di negara non-Islam.Karena mereka tidak beriman kepada Allah dan Nabi-Nya, maka mereka masuk neraka.Bukankah manusia tidak memilih dilahirkan di negara seperti ini, lalu bagaimana dengan keadilan Tuhan?

Fethullah Gülen menggarisbawahi bahwa pertanyaan ini memicu perebatan. Di satu sisi ia mengklaim perhatian besar kepada non-Muslim, dan di sisi yang lain menyusupkan kecaman terhadap Islam. Untuk menyelesaikan persoalan ini, Gülen menegaskan bahwa tidak ada pernyataan umum atau keputusan di dalam ajaran Islam bahwa orang yang hidup di negara non-Islam akan masuk neraka. Yang benar, ketetapannya adalah sebagai berikut:

Jika orang yang mendengar risalah dan ajakan nabi, dan menyaksikan kebenaran dan cahaya Islam, menolak dan berpaling darinya, maka ia akan masuk neraka. Perkara apakah orang yang mendengar risalah Ilahi itu berada di negara-negara Islam atau tidak, itu adalah tak terlalu penting; yang penting adalah bahwa mereka memperhatikan dan memenuhi risalah tersebut. Orang-orang yang tidak mematuhinya akan ke neraka-bahkan jika mereka dilahirkan dan tinggal di negara Islam. ${ }^{46}$

Dalam al-Quran memang ada ayat yang menyatakan: “...dan Kami bukanlah Penyiksa-penyiksa sebelum Kami mengutus seorang rasul' (QS. al-Isrā' [17]: 15). Ayat ini dipahami oleh banyak ulama sebagai kemurahan Ilahi sehingga siapa yang tidak dapat mengetahui tentang kehadiran ajaran rasul utusan Allah, maka ia tidak dituntut untuk mempertanggungjawabkan amal-amalnya yang melanggar, karena kesalahan yang dilakukannya lahir dari ketidaktahuan dan ketidakmampuan untuk mengetahui. Adapun yang tidak mengetahui tetapi ia berpotensi untuk tahu, maka ia tidak sepenuhnya bebas dari tanggung jawab. ${ }^{47}$ 
Dalam Tafsir al-Mishbāh, Quraish Shihab mengutip pemahaman sementara ulama pada kata rasūl pada ayat di atas (QS. al-Isrā' [17]: 15) dalam arti akal, sehingga seseorang yang memiliki potensi untuk mengetahui tetapi enggan menggunakan potensi itu untuk mengetahui dan mengamalkan kebenaran, maka ia tetap akan dituntut pertanggungjawabannya walaupun ia tidak mengetahui tentang kehadiran rasul yang membawa ajaran-ajaran kebenaran. ${ }^{48}$

Fethullah Gülen cenderung mendukung pendapat al-Matūridi yang menegaskan bahwa akal yang dimiliki manusia mampu membedakan mana yang baik dan mana yang buruk.Terjadi kekeliruan jika dikatakan akal dapat menangani segala sesuatu sendirian.Untuk alasan inilah Allah menggunakan rasul untuk menyampaikan aturan-aturan-Nya tentang mana yang baik dan mana yang buruk, dan tak memberikannya kepada penilaian dan pengalaman manusia yang bisa salah. ${ }^{49}$

Akal dapat mengatakan bahwa perzinahan adalah suatu kejahatan, karena praktik seperti itu memutus genealogis dan garis keturunan dan menyebabkannya hilang, yang, pada gilirannya, menyebabkan persoalan kewarisan dan lainnya. Akal dapat mengatakan bahwa mencuri itu, jahat sebab perbuatan itu membuat orang hidup tak aman; dan bahwa alcohol dan obat-obat memabukkan lainnya adalah jahat, karena semuanya itu menyebabkan orang kehilangan kesadaran, membahayakan kesehatan, membuat mereka rawan terhadap penyakit dan dapat memengaruhi keturunannya. Hal yang sama juga berlaku untuk hal-hal yang baik. Akal dapat memahami bahwa iman kepada Allah adalah baik, sebab itu membawa kita kepada kepuasan dan kegembiraan batin. Bahkan di dunia ini, kita mulai merasakan kesenangan yang kelak kita dapatkan di surga. ${ }^{50}$

Berdasarkan kenyataan ini, Fethullah Gülen menggarisbawahi peran akal dan pikiran di dalam iman.Ia memberi beberapa contoh orang-orang yang masuk Islam karena menggunakalkan akal, seperti 
Zaid bin Amr, paman 'Umar bin al-Khatțāb, yang dengan potensi akal yang dimilikinya ia mengetahui segera muncul seorang nabi, dia meninggalkan berhala dan menyembah Tuhan Yang Maha Esa. Meskipun ia meninggal sebelum Nabi Muhammad diangkat menjadi nabi, ia secara intuitif tahu bahwa Nabi akan datang. Pada saat menjelang ajalnya, ia memanggil putranya, Sa'īd, 'Umar, dan anggota keluarga lainnya: "Cahaya Allah telah berada di ufuk. Aku percaya ia akan segera muncul sepenuhnya. Aku telah merasakan tandatandanya di kepalaku.Jika Nabi sudah muncul, bergabunglah dengannya tanpa menunda-nunda lagi." 51 Dari penjelasannya ini, Fethullah Gülen menegaskan,

Orang-orang yang akan masuk neraka itu adalah mereka yang melihat atau mendengar tentang nabi dan al-Quran tetapi tidak mencari pengetahuan lebih jauh tentangnya. Mereka yang tetap dalam kegelapan dengan tak sengaja, karena mereka tak punya kesempatan untuk mendengarkan hal-hal ini, mungkin mendapatkan berkah Tuhan dan tidak disalahkan atau dikutuk karena perbuatan mereka yang keliru. ${ }^{52}$

Di bagian lain, Fethullah Gülen mengingatkan pentingnya untuk membawakan risalah Tuhan ini kepada orang-orang nonMuslim.Setiap Muslim berkewajiban mewartakan dan mengenalkan Nabi Muhammad. Sebab salah persoalan terbesar umat manusia adalah tidak mengenal sosok Nabi Terakhir tersebut secara utuh. Ini merupakan persoalan terbesar yang tengah dihadapi umat manusia. Karena itulah Allah menurunkan Nabi Muhammad untuk menerangi jalan kita sebagaimana yang telah Dia lakukan kepada nabi-nabi sebelumnya. Allah berfirman:

Sungguh Allah telah memberi karunia kepada orang-orang yang beriman ketika Allah mengutus diantara mereka seorang Rasul dari golongan mereka sendiri, yang membacakan kepada mereka ayat-ayat Allah, membersihkan (jiwa) mereka, dan mengajarkan kepada mereka al-Kitab dan al-Hikmah. dan sesungguhnya 
ANANG HADERI: Takdir dan Kebebasan

sebelum (kedatangan Nabi) itu, mereka adalah benar-benar dalam kesesatan yang nyata (QS. Ali 'Imrān [3]: 164).

Berdasarkan firman Allah ini, tegas Gülen, Allah mengutus Rasulullah untuk membimbing manusia menuju kebenaran dan membersihkan mereka dari dosa-dosa. Orang-orang yang dicerahkan oleh Rasulullah menemukan jalan menuju kehadiran Ilahi dan mencapai derajat kemanusiaan tertinggi. Gülen mengutip kata-kata Ibrahim al-Haqqi, "Allah berfirman bahwa Dia tidak bisa dimuat oleh langit dan bumi. Dia hanya bisa dikenal dan dicapai melalui hati." Inilah mengapa Rasulullah membimbing manusia menuju ke pengetahuan Allah. ${ }^{53}$ Lebih jauh Gülen menyatakan:

Those who follow this guidance are touched by Him in their innermost selves, whether it called heart, soul, or conscience, for only that can grasp God in His entirety. Minds cannot comprehend Him, and philosophy cannot reach Him. Therefore, the Prophets purified souls so they could be mirrors in which God might manifest Himself. Prophet Muhammad left us the Qur'an and Sunna to show us how to live in a way that fulfills the purpose for which the Prophets were sent. ${ }^{4}$

Orang-orang yang mengikuti bimbingannya disentuh oleh-Nya dalam diri mereka yang terdalam, entah itu dinamakan hati, jiwa, atau kesadaran, sebab hanya itulah yang bisa memahami Allah dalam keseluruhan-Nya. Pikiran tidak dapat memahami-Nya, dan filsafat tidak dapat mencapai-Nya. Oleh karena itu Nabi mensucikan jiwa agar mereka dapat menjadi cermin di mana Allah dapat memanifestasikan Diri-Nya. Nabi Muhammad mewariskan kepada kita al-Quran dan Sunnah untuk menunjukkan kepada kita bagaimana hidup dalam rangka memenuhi tujuan dari diutusnya para Nabi.

Ia lebih jauh mengingatkan, di akhirat orang-orang non-Islam akan ditanya mengapa mereka tidak memeluk Islam dan kita akan ditanya mengapa kita tidak menyampaikan Islam kepada mereka? Jadi, tegas Fethullah Gülen, 
Tanggung jawab Muslim dan non-Muslim harus dianggap sejajar. Setiap penilaian tentang non-Muslim harus dilakukan dengan adil dan jujur. Kita tidak dapat mengutuk non-Muslim masuk neraka hanya karena mereka itu non-Muslim, juga kita tak bisa bermimpi bahwa orang akan memeluk Islam hanya karena kita menyuruh mereka memeluknya. 55

Dari uraian di atas dapat ditarik benang merah mengenai posisi non-Muslim sepenuhnya tergantung pada Muslim itu sendiri dan non-Muslim.Bagi Muslim mempunyai kewajiban untuk mewartakan risalah Islam dengan berkarakter baik dan jiwanya terikat dengan Islam, bukan orang-orang Muslim yang tidak konsisten dan tidak cakap mengikuti keinginan dan kebutuhan jasmaninya saja dan hanya sesekali memperhatikan Islam. ${ }^{56}$ Sedangkan bagi non-Muslim, mereka telah dibekali dengan akal pikiran yang dengan itu ia harus berusaha mencari hidayah. Sebab, Tuhan, yang di dalam kasih-Nya yang tiada berkesudahan itu telah memberikan kepada manusia kesadaran dan kemauan yang diperlukannya untuk memperoleh pengetahuan dan memanfaatkan pengetahuan tersebut untuk menyadari tujuan hidup yang sesungguhnya. ${ }^{57}$

Tampaknya apa yang diingatkan oleh Gülen tersebut berangkat dari fitrah ketuhanan yang sudah melekat dalam diri manusia. Sebagaimana ditegaskan oleh Fazlur Rahman, bahwa petunjuk (hidāyah) sejatinya sejak sediakala sudah ditanamkan ke dalam diri manusia karena pengetahuan mengenai perbedaan di antara kebaikan dengan kejahatan "telah ditanamkan ke dalam hatinya" (QS. al-Syams [91]: 8) dan karena manusia telah mengucapkan ikrar untuk mengakui Allah sebagai Tuhannya (QS. al-A'rāf [7]: 172). ${ }^{58}$ Dengan demikian, seluruh manusia di mana pun ia berada di planet bumi ini sudah mempunyai potensi mengenal Tuhan ini. 


\section{E. Penutup}

Fethullah Gülen dalam menjelaskan tentang takdir dan kebebasan manusia ini tampaknya ingin memadukan antara ketentuan al-Quran (wahyu) dan potensi akal yang dimiliki manusia. Namun, di saat yang bersamaan ia juga mengingatkan manusia agar selalu konsisten di jalan takdir-dalam pengertian kebaikan-yang sudah digariskan Tuhan. Manusia dalam pandangannya memang mempunyai kehendak bebas, namun kehendak itu haruslah sesuai dengan kehendak Tuhan.

Dari uraian di atas, jelas terlihat bahwa Fethullah Gülen memahami takdir dan kehendak bebas yang sempat menjadi perdebatan di kalangan para teolog Muslim tidak sepenuhnya memihak kepada aliran mana pun. Ia mencoba menawarkan pemikiran teologinya sendiri dengan menggunakan bahasa yang bersifat menyentuh kesadaran nurani manusia. Wa Allāhu alam bi al-ṣawwāb.]

\section{Catatan Akhir}

${ }^{1}$ A. Athaillah, Rasyid Ridhä': Konsep Teologi Rasional dalam Tafsir al-Manār, Jakarta: Erlangga, 2006, h. 245.

2Sulaiman Al-Kumayi, Inilah Islam: Telaah terhadap Pemikiran Hasbi Ash-Shiddieqy dalam Bidang Tafsir, Feminisme, Teologi, NeoSufisme, dan Gagasan Menuju Fiqh Indonesia, Semarang: Pustaka Rizki Putra, 2006, h. 93-94.

3Yunan Yusuf, Corak Pemikiran Kalam Tafsir al-Azhar: Sebuah Telaah tentang Pemikiran Hamka Dalam Teologi Islam, Jakarta: Pustaka Panjimas, 1990, h. 62; Harun Nasution, Teologi Islam: Aliran-aliran, Sejarah, dan Analisa Perbandingan, Jakarta: UIP, 1986, h. 102.

${ }^{4}$ A. Athaillah, Rasyid Ridhä', h. 245.

${ }^{5} \mathrm{Abū}$ al-Ḥasan 'Alī ibn Ismā'îl al-Asy'arī, Maqālat al-Islāmiyìn wa Ikhtiläf al-Musallīn, Jil.. II, Cairo: Maktabah al-Nahḍah al-Mișriyah, 1373/1954, h. 199.

${ }^{6}$ A. Athaillah, Rasyid Ridhä', h. 245.

7Yunan Yusuf, Corak Pemikiran Kalam, h. 62-63. 
8Ibid., h. 67.

${ }^{9}$ Di Erzurum ini tarekat yang berkembang dan sangat berpengaruh adalah tarekat Naqshabandiyah, dan juga pengaruhpengaruh syaikh-syaikh sufi abad pertengahan seperti Rūmī, Ibn al'Arabī, dan al-Ghazālī; Erol Nazim Gulay, The Theological Thought of Fethullah Gülen: Reconciling Science and Islam, tesis M.Phil di St. Antony's College, Oxford University, 2007, h. 56.

${ }^{10}$ Bulent Aras dan Omer Caha, 'Fethullah Gülen and His Liberal “Turkish Islam” Movement,' dalam Barry Rubin [ed.], Revolutionaries and Reformers: Contemporary Islamist Movements in the Middle East, Albany: SUNY Press, 2003, h. 142; Erol Nazim Gulay, The Theological Thought, h. 56.

${ }^{11}$ Sulaiman Al-Kumayi, Islam Moderat: Analisis terhadap Pemikiran M. Fethullah Gülen Periode Pra dan Pasca Tragedi 11 September 2001, Semarang: Pusat Penelitian IAIN Walisongo, 52.

12 http://id.wikipedia.org/wiki/Fethullah_Gülen

${ }^{13}$ Irwan Masduqi, Berislam Secara Toleran: Teologi Kerukunan Umat Beragama, Bandung: Mizan, 2011, h. 147.

${ }^{14}$ Ika Yunia Fauzia, "Menguak Konsep Kebersandingan Fethullah Gulen dan Asimilasi Budaya Tariq Ramadan", ISLAMICA, Vol. 3, No. 2, Maret 2009, h. 5.

15Buku-buku Fethullah Gülen yang telah diterjemahkan dalam bahasa Indonesia adalah Kunci-kunci Rahasia Sufi (2001), Memadukan Akal dan Kalbu Dalam Beriman (2002), Menghidupkan Iman Dengan Mempelajari Tanda-tanda Kebesaran-Nya (2002), Versi Terdalam: Kehidupan Rasulullah Muhammad SAW (2002), Cahaya al-Quran Bagi Seluruh Makhluk (2011), Dakwah: Jalan Terbaik Dalam Berpikir dan Menyikapi Hidup (2011), Bangkitnya Spiritualitas Islam (2012), dan Cahaya Abadi Muhammad SAW Kebanggaan Umat (2012).

${ }^{16}$ Sulaiman Al-Kumayi, "Konsep Sufisme 'Shakhs-I Manevi dan Hizmet Muhammad Fethullah Gülen", Ulumuna: Jurnal Studi Keislaman, Vol. 17, No. 2 (Desember) 2013.

${ }^{17}$ M. Fethullah Gülen, Essential of the Islamic Faith, Feedbooks, 2005, h. 77.

18Ibid., h. 78.

${ }^{19}$ Ibid.

20 Ibid.

${ }^{21}$ Naqiyah Mukhtar, "Imām" dalam M. Quraish Shihab (Editor Kepala), Ensiklopedia al-Quran: Kajian Kosa Kata, Vol. I, Jakarta: 
Lentera Hati-Pusat Studi al-Qur'an-Yayasan Paguyuban Ikhlas, 2007, h. 350.

22M. Fethullah Gülen, Essential, h. 80.

23Ibid.

${ }^{24}$ Arifuddin Ahmad, "Mubīn" dalam M. Quraish Shihab (Editor Kepala), Ensiklopedia al-Quran: Kajian Kosa Kata, Vol. II, Jakarta: Lentera Hati-Pusat Studi al-Qur'an-Yayasan Paguyuban Ikhlas, 2007, h. 618.

25M. Fethullah Gülen, Essential, h. 80.

26Ibid.

27Ibid., h. 80.

28Ibid., h. 81.

29Ibid.

${ }^{30}$ Muhammad Rasyīd Rị̣ā, Tafsīr al-Manār, Jil.. V, Kairo: Dār alMa'rifah, t.th., h. 270.

${ }^{31}$ M. Fethullah Gülen, Essential, h. 81.

${ }^{32}$ Ibid., h. 90-91.

33Ibid., h. 91.

${ }^{34}$ Ibid.

${ }^{35}$ Ayat senada: "Barangsiapa yang dikehendaki Allah (kesesatannya), niscaya disesatkan-Nya, dan barangsiapa yang dikehendaki Allah (untuk diberi-Nya petunjuk), niscaya Dia menjadikan-Nya berada di atas jalan yang lurus (QS. al-An'ām [6]: 39).

36M. Fethullah Gülen, Memadukan Akal dan Kalbu dalam Beriman, terj. Tri Wibowo Budi Santoso, Jakarta: RajaGrafindo Persada, 2002, h. 135.

${ }^{37}$ M. Fethullah Gülen, Cahaya al-Quran bagi Seluruh Makhluk: Tafsir Ayat-ayat Pilihan Sesuai Dunia Saat Ini, terj. Ismail Ba'adillah, Jakarta: Republika Penerbit, 2011, h. 138.

38Ibid.

${ }^{39}$ Muhammad Rasyīd Riḍā, Tafsīr al-Manār, Jil.. VII, Kairo: Dār alMa'rifah, t.th., h. 402.

40Ibid., h. 188.

${ }^{41} \mathrm{http}: / /$ www.fgulenchair.org/index.php?option=com_content\& view=article\&id=146:rasionalitas-dan-dualisme-

akal\&catid=19:membangun-peradaban-kita (akses 22 April 2014).

${ }^{42}$ Ibid.

${ }^{43}$ M. Fethullah Gülen, Cahaya al-Quran, h. 79.

${ }^{44}$ M. Fethullah Gülen, Memadukan Akal, h. 139. 
45M. Fethullah Gülen, Bangkitnya Spiritualitas Islam, terj. Fuad Saefuddin, Jakarta: Republika Penebrbit, 2012, h. 36.

46M. Fethullah Gülen, Memadukan Akal, h. 140.

${ }^{47}$ M. Quraish Shihab, Tafsir al-Mishbāh: Pesan, Kesan dan Keserasian al-Qur'an, Vol. VII, Jakarta: Lentera Hati, 2002, h. 431.

${ }^{48}$ Ibid.

${ }^{49}$ M. Fethullah Gülen, Memadukan Akal, h. 141.

50Ibid.

51Ibid., h. 142.

52Ibid, h. 142-143.

53M. Fethullah Gülen, The Messenger of God Muhammad: an Analysis of the Prophet's Life, New Jersey: The Light, 2006, h. 23.

${ }^{54}$ Ibid., h. 23.

${ }^{55}$ M. Fethullah Gülen, Memadukan Akal, h. 148.

56Ibid., h. 149.

57Fazlur Rahman, Tema Pokok al-Qur'an, terj. Anas Mahyuddin, Bandung: Pustaka, 1983, h. 13.

${ }^{58}$ Ibid. 


\section{DAFTAR PUSTAKA}

Ahmad, Arifuddin, "Mubīn" dalam M. Quraish Shihab (Editor Kepala), Ensiklopedia al-Quran: Kajian Kosa Kata, Vol. II, Jakarta: Lentera Hati-Pusat Studi al-Qur'an-Yayasan Paguyuban Ikhlas, 2007.

Aras, Bulent, dan Omer Caha, 'Fethullah Gülen and His Liberal "Turkish Islam" Movement,' dalam Barry Rubin [ed.], Revolutionaries and Reformers: Contemporary Islamist Movements in the Middle East, Albany: SUNY Press, 2003.

Asy'arī, Abū al-Ḥasan 'Alī ibn Ismā'īl, Maqālat al-Islāmiyīn wa Ikhtilāf al-Musallīn, Jil. II, Cairo: Maktabah al-Nahḍah al-Mișriyah, 1373/1954.

Athaillah, A., Rasyid Ridhā': Konsep Teologi Rasional dalam Tafsir alManār, Jakarta: Erlangga, 2006.

Fauzia, Ika Yunia, "Menguak Konsep Kebersandingan Fethullah Gülen dan Asimilasi Budaya Tariq Ramadan", ISLAMICA, Vol. 3, No. 2, Maret 2009.

Gulay, Erol Nazim, The Theological Thought of Fethullah Gülen: Reconciling Science and Islam, tesis M.Phil di St. Antony's College, Oxford University, 2007.

Gülen, M. Fethullah, Memadukan Akal dan Kalbu dalam Beriman, terj. Tri Wibowo Budi Santoso, Jakarta: RajaGrafindo Persada, 2002.

Gülen, M. Fethullah,Essential of the Islamic Faith, Feedbooks, 2005.

Gülen, M. Fethullah, The Messenger of God Muhammad: an Analysis of the Prophet's Life, New Jersey: The Light, 2006.

Gülen, M. Fethullah,Cahaya al-Quran bagi Seluruh Makhluk: Tafsir Ayat-ayat Pilihan Sesuai Dunia Saat Ini, terj. Ismail Ba'adillah, Jakarta: Republika Penerbit, 2011.

Gülen, M. Fethullah, Bangkitnya Spiritualitas Islam, terj. Fuad Saefuddin, Jakarta: Republika Penebrbit, 2012. 
http://www.fGülenchair.org/index.php?option=com_content\&view= article\&id=146:rasionalitas-dan-dualisme-

akal\&catid=19:membangun-peradaban-kita (akses 22 April 2014).

Kumayi, Sulaiman, Inilah Islam: Telaah terhadap Pemikiran Hasbi Ash-Shiddieqy dalam Bidang Tafsir, Feminisme, Teologi, NeoSufisme, dan Gagasan Menuju Fiqh Indonesia, Semarang: Pustaka Rizki Putra, 2006.

Kumayi, Sulaiman, Islam Moderat: Analisis terhadap Pemikiran M. Fethullah Gülen Periode Pra dan Pasca Tragedi 11 September 2001, Semarang: Pusat Penelitian IAIN Walisongo, 2011.

Kumayi, Sulaiman, "Konsep Sufisme 'Shakhs-I Manevi dan Hizmet Muhammad Fethullah Gülen", Ulumuna: Jurnal Studi Keislaman, Vol. 17, No. 2 (Desember) 2013.

Masduqi, Irwan, Berislam Secara Toleran: Teologi Kerukunan Umat Beragama, Bandung: Mizan, 2011.

Mukhtar, Naqiyah, "Imām” dalam M. Quraish Shihab (Editor Kepala), Ensiklopedia al-Quran: Kajian Kosa Kata, Vol. I, Jakarta: Lentera Hati-Pusat Studi al-Qur'an-Yayasan Paguyuban Ikhlas, 2007.

Nasution, Harun, Teologi Islam: Aliran-aliran, Sejarah, dan Analisa Perbandingan, Jakarta: UIP, 1986.

Rahman, Tema Pokok al-Qur'an, terj. Anas Mahyuddin, Bandung: Pustaka, 1983.

Riḍā, Muḥammad Rasyīd, Tafsīr al-Manār, Jil. V dan VII, Kairo: Dār alMa'rifah, t.th.

Shihab, M. Quraish, Tafsir al-Mishbāh: Pesan, Kesan dan Keserasian alQur'an, Vol. VII, Jakarta: Lentera Hati, 2002. 